\title{
IDENTIFIKASI KERAGAMAN GEN TOLL-LIKE RECEPTOR-4 PADA AYAM TOLAKI, AYAM PETELUR KOMERSIAL DAN AYAM BROILER
}

\author{
Niken Ulupi ${ }^{1 *}$ dan Muhammad Amrullah Pagala ${ }^{2}$ \\ ${ }^{1)}$ Departemen IPTP, Fakultas Peternakan, Institut Pertanian Bogor, Bogor \\ ${ }^{2)}$ Jurusan Peternakan, Fakultas Peternakan, Universitas Halu Oleo, Kendari \\ e-mail : niken.ulupi@gmail.com
}

\begin{abstract}
ABSTRAK
Gen Toll-like Receptor 4 (TLR4) adalah salah satu gen yang mengontrol ketahanan ayam terhadap serangan Salmonella $s p$, melalui respon immun non-specific. Gen ini dapat digunakan sebagai marka genetik pada ayam. Oleh karena itu penelitian ini bertujuan mengevaluasi polimorfisme genetik gen TLR4 pada beberapa jenis ayam (Ayam Tolaki, Ayam Ras pedaging dan petelur). Total sampel sebanyak 126. Penelitian ini melalui 3 tahapan yakni ekstraksi DNA, amplifikasi PCR (dengan ukuran DNA 220 pb pada ekson 2), dan metode RFLP menggunakan enzim MscI. Hasil penelitian menunjukkan gen TLR4 $\mid$ MscI bersifat polimorfik pada semua jenis ayam. Diperoleh 2 alel (A dan G). Frekuensi alel G (membawa sfat resisten) pada ayam Tolaki, Ras pedaging, dan petelur masing-masing $0.77,0.87$ dan 0.20 . Nilai $x^{2}$ menunjukkan genTLR4|MscI berada dalan keseimbangan Hardy-Weinberg dengan Ho dan $\mathrm{He} 0,31$ dan 0,29. Nilai PIC 0,25 termasuk kategori medium. Gen TLR4| MscI dapat digunakan sebagai marka genetik sifat ketahanan ayam Tolaki terhadap infeksi Salmonellasp.
\end{abstract}

Kata Kunci : Polimorfik, Gen TLR4, Salmonella sp., Non-Specific Immune Response

\begin{abstract}
Toll-like Receptor 4 (TLR4) gene is one ofthe genesthat controlresistance of chickens against Salmonella sp. Through non-specific immune response. These gene can be used asgenetic marker sinchickens, if known its diversity.Therefore this research was aimed at evaluating the genetic polymorphism of TLR4 gene in several types of chickens (Tolaki chicken, broiler chicken and commercial laying hen). The total of samples were 126. Therewere three stages of identification : extraction of DNA genom, PCR amplification of TLR4 gene (with size 220 bp on exon 2), and RFLP method using restriction enzym $(M s c \mathrm{I})$. The data were analyzed include frequency of allele, frequency of genotype, heterozygosity values, and value of Polymorphic Informative Content (PIC). The results showed that TLR4|MscI was found polymorphic in all kind of chickens that was genotyped. It were found two alleles (A and G). Frequency of $G$ allele (carrier of resistantcharacter) on Tolaki chickens, broilers and laying hens were $0.77,0.87$ and 0.20 . The value of $x^{2}$ showed that TLR4|MscI in Tolaki chicken was in Hardy-Weinberg equilibrium, with Ho and He value were 0. 31 and 0.29. The PIC value of TLR4 gene of Tolaki chicken (0.25) included in the category of medium. These results declared that TLR4|MscI gave hopefor used as genetic marker sin resistance to Salmonella sp .infection in Tolaki chickens.
\end{abstract}

Keywords : Polimorphism, TLR4 gene, Salmonella sp., non-specific immune response 


\section{PENDAHULUAN}

Ayam lokal Indonesia memiliki banyak keragaman, dengan karakteristik morfologis yang berbeda. Ayam lokal ini merupakan aset yang berharga dalam pembentukan bibit unggul, karena ayam lokal terbukti mampu beradaptasi dengan baik terhadap lingkungan setempat (Nataamijaya 2010). Ayam lokal memiliki potensi untuk dikembangkan sebagai penghasil daging, penghasil telur, sebagai hobi, atau dikembangkan untuk memenuhi fungsi sosial budaya yang berlaku di berbagai wilayah di Indonesia.

Ayam lokal ini ada yang spesifik dan yang tidak spesifik. Ayam lokal yang tidak spesifik adalah ayam lokal yang tidak mempunyai ciri atau karakteristik yang khusus dan tersebar diseluruh wilayah Indonesia. Adapun ayam lokal yang spesifik adalah ayam lokal yang mempunyai ciri khas dan hanya ditemukan serta berkembang di wilayah tertentu.

Salah satu ayam lokal yang spesifik adalah ayam Tolaki. Ayam ini berkembang di Kabupaten Konawe dan Konawe Selatan, Propinsi Sulawesi Tenggara. Ciri khas yang dimiliki oleh ayam Tolaki adalah berbobot badan kecil, tangkas dan agresif (Sulandari et al., 2007). Ayam ini mampu menghasilkan produksi telur diatas ratarata ayam lokal yang lain, yaitu sekitas 20 butir per periode bertelur (Pagala, 2014). Daging ayam Tolaki mempunyai rasa yang lebih lezat dari pada ayam lokal Indonesia yang lain. Oleh sebab itu ayam ini sangat diminati dan diburu oleh masyarakat.

Telur ayam Tolaki, sebagaimana telur ayam lokal yang lain, sebagian besar dimanfaatkan oleh masyarakat setempat sebagai jamu, dan dikonsumsi secara langsung tanpa melalui pemasakan. Sebesar $44 \%$ kasus salmonellosis di dunia disebabkan karena mengkonsumsi telur yang tidak matang secara sempurna (Ochiai et al., 2008). Hasil isolasi kejadian salmonellosis tersebut ternyata sebagian besar disebabkan oleh bakteri Salmonella enteritidis (Velge et al., 2005).

Dengan demikian masyarakat yang mengkonsumsi telur ayam Tolaki sebagai jamu ini sangat berpeluang tertular salmonellosis. Oleh sebab itu keberadaan telur bebas Salmonella menjadi sangat penting. Telur bebas Salmonella hanya diproduksi oleh ayam yang memiliki ketahanan tinggi terhadap bakteri tersebut.

Tingginya tingkat ketahanan atau resistensi ayam terhadap Salmonella dipengaruhi oleh faktor genetik, faktor lingkungan dan interaksi kedua faktor tersebut. Sebagai faktor genetik, resistensi ayam terhadap Salmonella $s p$. dikontrol oleh banyak gen. Salah satunya adalah gen Toll-like Receptor 4(TLR4) (Calenge et al., 2010). Beberapa hasil penelitian menyatakan bahwa gen TLR4 merupakan salah satu gen kandidat pada sifat ketahanan ayam terhadap infeksi bakteri $S$. enteritidis (Kramer et al., 2003; Lamont et al., 2002).

Gen TLR4 pada ayam berada pada kromosom 17. Berdasarkan data dari GenBank(dengan nomor akses : A Y064697.1), gen TLR4 berukuran 11698 pb. Struktur gen TLR4 diawali oleh wilayah promoter $(2743 \mathrm{pb})$, exon 1, 2, dan 3 (105, 167 dan 3260 bp),intron 1 dan 2 (934 dan 984 pb), dan diakhiri oleh flankingregion (3505 $\mathrm{pb})$.

Gen TLR4 berperan dalam mengaktivasi respon imun non spesifik. Gen TLR4 mentranskripsi protein yang berfungsi sebagai reseptor permukaan sel fagosit. Protein reseptor ini mampu mengenali lipopolisakarida (LPS) dari 
bakteri gram negatif, termasuk Salmonella, dengan demikian gen TLR4 ini dapat diaktivasi oleh LPS. (Emertcan et al., 2011; Animura et al., 2008; Akira dan Takeda, 2004; Palsson dan O'Neill, 2004; Akashi et al., 2001).

Secara tidak langsung gen TLR4 juga mempengaruhi respons imun spesifik yang diperantarai oleh limfosit $\mathrm{T}$ dan limfosit $\mathrm{B}$, seperti dinyatakan oleh Kabelitz (2007), bahwa gen TLR4 juga dapat berekspresi dalam limfosit $\mathrm{T}$. Gen TLR4 ini berekspresi kuat tidak hanya pada ternak ayam.

Pada manusia dan tikus, telah dibuktikan bahwa terjadinya mutasi pada gen TLR4, berdampak terhadap penurunan kemampuan individu dalam mengenali LPS dari bakteri Salmonella $s p$. Individu tersebut menjadi peka dan mudah terinfeksi Salmonella (Lorenz et $a l ., 2002$ ). Adanya mutasi menyebabkan gen TLR4 membentuk beberapa genotipe. Abasht et al. (2009) menyatakan bahwa adanya variasi genotipe gen TLR4 pada ayam berpengaruh pada ketahanannya terhadap infeksi bakteri Salmonellasp.

Penelitian ini bertujuan untuk mengidentifikasi keragaman gen TLR4 pada ayam Tolaki, ayam petelur komersial dan ayam broiler, menggunakan metode PCR-RFLP. Hasil penelitian ini diharapkan memperoleh informasi genetik mengenai keragaman gen tersebut pada ayam Tolaki dibandingkan dengan ayam ras yang beredar di Indonesia.

\section{METODE PENELITIAN}

Penelitian dilakukan dari awal bulan April sampai akhir bulan Mei tahun 2013. Penelitian dilaksanakan di laboratorium Pemuliaan dan Genetika Ternak Molekuler, Departemen Ilmu Produksi dan Teknologi Peternakan, Fakultas Peternakan, Institut Pertanian
Bogor.

Total sampel yang diidentifikasi sebanyak 126, terdiri atas ayam Tolaki 82 ekor, ayam petelur 20 ekor dan ayam broiler 24 ekor. Identifikasi keragaman gen TLR4 beberapa rumpun ayam lokal Indonesia dilakukan tiga tahap, yaitu ekstraksi DNA genom (Sambrook et al., 1989), amplifikasi PCR gen TLR4. Tahap ketiga adalah menentukan genotipe gen TLR4 dengan metode RFLP

(RestrictionFragmentLengthPolymorphi sm).

\section{Polymerase Chain Reaction- Restriction Fragment Length Polymorphism (PCR-RFLP)}

Reaksi PCR menggunakan disain primer sebagai berikut : primer forward : 5'-GCT CAA ATT ATT TTT CAT CAG Tgg CC-3' dan primer reverse : 5'-ATC TGG ACT AAA AGC TGC AC-3'. Fragmen gen TLR4 yang diamplifikasi dengan primer tersebut berukuran $220 \mathrm{pb}$. Primer tersebut didisain sendiri dengan menggunakan bantuan Primer Designing Tools Program (http://www.ncbi.nlm. nih.gov/tools /primer-blast).

Amplifikasi DNA dilakukan pada total volume $25 \mu \mathrm{l}$, terdiri dari $2 \mu \mathrm{l}$ DNA, $15,75 \mu 1$ air bebas ion steril, 2,5 $\mu 1$ 10x buffer tanpa $\mathrm{Mg}^{2+}, 2 \mu \mathrm{MgCl}_{2}$, $0,5 \mu 1 \quad 10 \mathrm{mM}$ dNTP, 0,25 $\mu \mathrm{l}$ Taq polimerase, $2 \mu \mathrm{l}$ primer. Tahap pertama dilakukan satu siklus, meliputi proses denaturasi awal pada $94^{\circ} \mathrm{C}$ selama 4 menit. Tahap kedua dilakukan 30 siklus. Setiap siklusnya terdiri dari denaturasi $\left(94^{\circ} \mathrm{C}\right.$, selama 10 detik), annealing $\left(60^{\circ} \mathrm{C}\right.$, selama 1 menit) dan ekstensi $\left(72^{\circ} \mathrm{C}\right.$, selama 2 menit). Tahap ketiga adalah ekstensi akhir $\left(72^{\circ} \mathrm{C}\right.$, selama 7 menit). Selanjutnya diinkubasi pada suhu $4^{\circ} \mathrm{C}$ hingga digunakan untuk analisis lebih lanjut. Proses amplifikasi 
ini memggunakan GeneAmp PCR system 9700 Applied Byosistem

Penentuan genotipe menggunakan metode RFLP. Fragmen gen TLR4 yang merupakan produk PCR, sebanyak $4 \mu \mathrm{l}$ dipotong dengan restriction endonuclease mix, yang terdiri dari 2 $\mu \mathrm{l}: \mathrm{dH} 2 \mathrm{O}(1 \mu \mathrm{l})$, buffer $(0,7 \mu \mathrm{l})$, dan 0,3 $\mu \mathrm{l} \mathrm{MscI}$ selama 16 jam pada suhu $37^{\circ} \mathrm{C}$. Produk PCR yang sudah dipotong dengan enzim restriksi, kemudian divisualisasikan dengan elektroforesis menggunakan gel agarose 2\% dengan buffer 0,5 TBE (Tris Borat EDTA) yang dijalankan pada tegangan $100 \mathrm{~V}$ selama 40 menit di bawah UV trans iluminator. Enzim pemotong $(M s c \mathrm{I})$, mengenali situs potong $\mathrm{TGG} \mid \mathrm{CCA}$.

\section{Analisis Data}

Nilai frekuensi alel, frekuensi genotipe, heterozigositas pengamatan (Ho), dan heterozigositas harapan (He), dihitung berdasarkan rumus dari Nei (1987). Nilai keseimbangan HardyWeinberg dihitung dengan rumus dari Hartl dan Clark (1997), dan nilai Polymorphic Informative Content (PIC) dihitung berdasarkan rumus dari Bostein et al. (1980).

\section{HASIL DAN PEMBAHASAN}

\section{Genotipe GenTLR4 pada AyamTolaki dan Persilangannya dengan Ayam Broiler}

Genotyping gen TLR4 dilakukan pada exon 2 (basa ke 3898-4117), dengan produk PCR berukuran $220 \mathrm{pb}$, seperti disajikan pada Gambar 1 . Adapun visualisasi hasil elektroforesis dari penelitian ini disajikan dalam Gambar 2.

Gambar 1 dan 2 adalah fragmen gen TLR4 yang berukuran $220 \mathrm{pb}$ pada exon 2 yang merupakan produk PCR. Selanjutnya dipotong oleh enzim restriksi MscI, pada situs ke 3924 dengan posisi titik potong TGG|CCA.

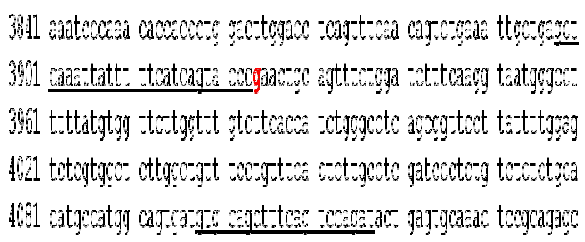
Gambar $\begin{gathered}\text { 1.Sekuen gen } \\ \text { diamplifikasi }\end{gathered}$
(GenBankA Y064697.1). Posisi primer menempel pada nukleutida yang bergaris bawah.

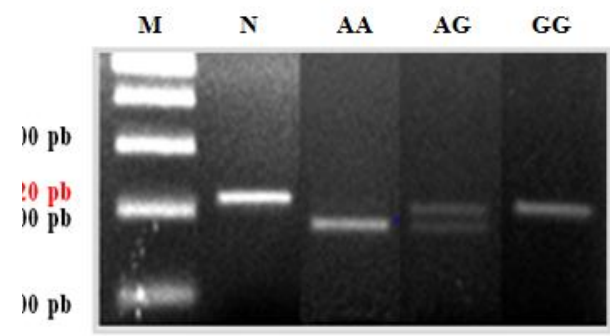
Gambar
2. Produk PCR-RFLP genTLR4|MscIpada exon 2
$\mathrm{M}:$ marker $100 \mathrm{pb}$.
$\mathrm{N}$ : fragmen gen TLR4 (220 pb). AA, AG dan GG : genotipe gen TLR4 (Ulupi et al., 2013)

Pemotongan oleh enzim $M s c I$ menghasilkan alel A dan alel G. Alel A berukuran $24 \mathrm{pb}$ dan $196 \mathrm{pb}$, dan alel G berukuran $220 \mathrm{pb}$. Adapun AA, AG dan GG adalah genotipe gen TLR4 ayam lokal yang diidentifikasi.

Dari hasil genotyping ini, terditeksi adanya mutasi pada situs ke 3924. Mutasi ini menyebabkan terjadinya perubahan basa dari guanin (G) menjadi Adenin (A). Perubahan nukleutida ini menyebabkan terjadinya perubahan asam amino, dari asam glutamat (GAA) menjadi lisin (AAA). Hasil penelitian ini serupa dengan yang dilaporkan oleh Beaumontet al. (2003), 
Tabel 1. Nilai frekuensi alel dan frekuensi genotipe gen TLR4 pada ayam Tolaki, ayam petelur dan broiler

\begin{tabular}{|c|c|c|c|c|c|}
\hline \multirow{2}{*}{ Jenis ayam } & \multirow{2}{*}{$\begin{array}{l}\text { Jumlah } \\
\text { sampel }\end{array}$} & \multicolumn{2}{|c|}{ Frekuensi alel } & \multicolumn{2}{|c|}{ Frekuensi genotipe } \\
\hline & & A & $\mathrm{G}$ & AA & $\mathrm{AG}$ \\
\hline Tolaki & 82 & 0.18 & 0.82 & 0.02 & 0.31 \\
\hline Petelur komersial & 20 & 0.80 & 0.20 & 0.60 & 0.40 \\
\hline Broiler & 24 & & & & \\
\hline
\end{tabular}

yang melakukan genotyping pada ayam petelur coklat komersial (commercial brownlaying hens).

\section{Frekuensi Alel dan Frekuensi Genetik}

Nilai frekuensi alel dan frekuensi genotipe gen TLR4 pada lokus MscI pada ayam Tolaki dan persilangannya dengan ayam broiler disajikan pada Tabel 1.

Pada ayam Tolaki dan ayam broiler, frekuensi alel didominasi oleh alel G. Pada ayam petelur, gen TLR4 didominasi oleh alel A (80\%). Nilai frekuensi alel $\mathrm{G}$ pada ketiga jenis ayam tersebut berkisar antara 0.20-0.87. Ulupi (2014) menyatakan bahwa alel G pada gen TLR4 ayam Kampung adalah membawa sifat resisten, dengan dihasilkannya respons fisiologis yang lebih tinggi dari pada alel A. Dengan demikian frekuensi alel pembawa sifat resisten terhadap Salmonella sp. pada ayam Tolaki adalah sangat tinggi $(82 \%)$, demikian juga pada ayam broiler $(87 \%)$.

Pada penelitian ini, gen TLR4 pada ayam Tolaki teridentifikasi tiga macam genotipe, yaitu AA, AG, dan GG. Masing-masing genotipe tersebut frekuensinya $0.02,0.31$, dan 0.67 . Pada ayam petelur dan ayam broiler hanya ditemukan 2 genotipe. Genotipe gen TLR4 pada ayam petelur adalah AA dan $\mathrm{AG}$, yang frekuensinya didominasi oleh
AA $(60 \%)$. Adapun genotipe gen TLR4 pada ayam broiler adalah AG dan GG. Frekuensi genotipe GG pada ayam broiler adalah sangat tinggi, yaitu $75 \%$.

Hasil genotyping dalam penelitian ini dapat diartikan bahwa gen TLR4 pada lokus $M s c I$ bersifat polimorfik (beragam). Hal ini sesuai dengan pernyataan Nei dan Kumar (2000), bahwa jika terdapat sedikitnya dua alel atau dua genotipe, dengan nilai frekuensi relatif dalam populasi lebih dari $0,01 \quad(1 \%)$, maka disebut polimorfik. Keragaman gen TLR4 juga telah dilaporkan terjadi pada beberapa bangsa ayam (Ruan et al., 2012), pada ayam ras petelur(Beaumont et al., 2003), pada ayam pedaging atau ayam broiler (Malek et al., 2004), pada ayam lokal cina (Li et al., 2013; Liu et al., 2011), dan pada ayam Kampung (Ulupi et al., 2013).

\section{Keseimbangan Gen Toll-like Receptor4 dalam Populasi}

Keseimbangan gen TLR4 dalam populasi (keseimbangan HardyWienberg) diuji dengan chi-square $(x)^{2}$. Hasil pengujian terhadap gen TLR4 pada lokus MscI, disajikan pada Tabel 2. 
Tabel 2. Hasil uji chi-square $\left(x^{2}\right)$ frekuensi genotipe gen TLR4 ayam Tolaki, ayam petelur dan ayam broiler

\begin{tabular}{lc}
\hline Jenis ayam & Nilai $x^{2}$ \\
\hline Tolaki & $0.19^{\text {tn }}$ \\
Petelur komersial & $0.06^{\text {td }}$ \\
Broiler & $0.45^{\text {td }}$ \\
\hline
\end{tabular}

tn : tidak berbeda nyata, $x_{(0.05,1)}^{2}=3.84$

td : tidak dianalisis karena $\mathrm{db}=0$

Nilai $x^{2}$ genotipe gen TLR4 pada ayam petelur komersial dan ayam broiler tidak dianalisis. Hal ini disebabkan karena jumlah genotipe gen TLR4 ditemukan dua macam yaitu AA dan AG (untuk ayam petelur) dan AG dan GG (untuk ayam broiler). Jumlah alel yang ditemukan juga dua yaitu alel A dan alel G. Setelah dihitung berdasarkan rumus dari Allendorf dan Luikart (2007), diperoleh nilai nol pada derajat bebasnya. Hal ini menyebabkan nilai $x^{2}$ pada kedua jenis ayam ini tidak dapat dianalisis. Pada ayam Tolaki terlihat bahwa frekuensi genotipe gen TLR4 berada dalam keseimbangan Hardy-Wienberg.

Suatu populasi dinyatakan dalam keadaan keseimbangan HardyWeinberg, apabila frekuensi genotipe $\left(\mathrm{p}^{2}, 2 \mathrm{pq}, \mathrm{q}^{2}\right)$ dan frekuensi alel ( $\mathrm{p}$ dan $\left.\mathrm{q}\right)$ adalah konstan dari generasi ke generasi, akibat penggabungan gamet yang terjadi secara acak dalam populasi yang besar (Vasconcellos et al. 2003).

Keseimbangan genotipe dalam populasi yang cukup besar terjadi jika tidak ada seleksi, mutasi, migrasi dan genetic drift. Genetic drift adalah perubahan frekuensi genotipe yang diakibatkan oleh fluktuasi acak akibat adanya peluang dalam pola perkawinan, kesalahan pengambilan sampel, dan perubahan frekuensi mendadak akibat adanya faktor lingkungan (misalnya bencana alam). Sebaliknya jika terjadi akumulasi genotipe, populasi yang terbagi, mutasi, seleksi, migrasi dan perkawinan dalam kelompok yang sama (endogami), dapat menimbulkan ketidakseimbangan frekuensi genotipe atau frekuensi alel dalam populasi tersebut.

Keseimbangan genotipe gen TLR4 lokus $M s c$ I pada ayam Tolaki ini, memperlihatkan bahwa intersitas kejadian mutasi, endogami, seleksi yang intensif serta migrasi pada kedua rumpun ayam lokal tersebut bisa dikatakan sangat rendah. Ayam Tolaki selama ini dipelihara oleh masyarakat secara ekstensif (dengan diumbar), hal ini memungkinkan terjadinya perkawinan secara acak dari generasi ke generasi.

Tabel 3. Nilai heterozigositas pengamatan $\left(\mathrm{H}_{\mathrm{o}}\right)$ dan heterozigositas harapan $\left(\mathrm{H}_{\mathrm{e}}\right)$ dan nilai Polymorphic Informative Content (PIC) genotipe gen TLR4

\begin{tabular}{lllll}
\hline Jenis ayam & Jumlah sampel & Ho & He & PIC \\
\hline Tolaki & 82 & 0.31 & 0.29 & 0.25 \\
Petelur komersial & 20 & 0.40 & 0.32 & 0.27 \\
Broiler & 24 & 0.25 & 0.23 & 0.20 \\
\hline
\end{tabular}

Keterangan : Ho : heterozigositas pengamatan

$\mathrm{He}$ : heterozigositas harapan

PIC : Polymorphic Informative Content 
Nilai Heterozigositas dan Polymorphic Informative Content

Nilai heterozigositas merupakan rataan persentase lokus heterozigot tiap individu atau rataan persentase individu heterozigot dalam populasi (Nei dan Kumar, 2000). Heterozigositas yang tinggi menunjukkan tingginya keragaman genetik dalam suatu populasi dan sebaliknya. Adapun nilai Polymorphic Informative Content (PIC) merupakan salah satu parameter yang menunjukkan tingkat informatifnya suatu penciri (marker) (Botstein et al., 1980).

Hasil analisis pendugaan nilai heterozigositas dan PIC gen TLR4|MscI pada ayam Tolaki, ayam petelur dan ayam broiler disajikan pada Tabel 3 .

Nilaiheterozigositas pengamatan gen TLR4|MscI pada ketiga jenis ayam yang dianalisis berkisar antara 0.25-0.40. Nilai heterozigositas pengamatan genotipe gen TLR4 pada ayam petelur dalam penelitian adalah tertinggi, yaitu 0.40. Ini berarti bahwa frekuensi genotipe yang gen TLR4 yang homozigot pada pada ayam petelur adalah 0.6. Genotipe gen TLR4 pada ayam petelur komersial hanya ditemukan 2 macam, yaitu AA dan AG. Oleh sebab itu $60 \%$ frekuensi genotipe gen TLR4 yang homozigot, semuanya bergenotipe AA. Genotipe ini adalah pembawa sifat peka terhadap infeksi Salmonella sp. Berbeda dengan genotipe gen TLR4 pada ayam Tolaki dan broiler. Nilai heterozigositas genotipe gen TLR4 pada kedua ayam tersebut lebih rendah dari pada ayam petelur, tetapi genotipe yang homozigot didominasi oleh GG yang merupakan pembawa sifat resisten.

Nilai heterozigositas pengamatan (Ho) dan heterozigositas harapan (He : 0.23-0.32) pada lokus TLR4|MscI tidak mengindikasikan adanya perbedaan yang besar. Nilai heterozigositas pengamatan (Ho) dan heterozigositas harapan $(\mathrm{He})$ ini dapat digunakan untuk menduga nilai inbreeding pada suatu kelompok ternak.

Hasil pendugaan nilai PIC gen TLR4 lokus $M s c$ I pada ayam Tolaki, ayam petelur dan ayam broiler yang dianalisis berkisar antara 0.20-0.27. Botstein et al. (1980) menyatakan bahwa kriteria PIC termasuk dalam kelompok rendah jika nilai PIC $\leq$ 0.25 , nilai PIC termasuk katagori sedang adalah antara $0.25<$ PIC $<0.5$, dan termasuk kategori tinggi bila nilai $\mathrm{PIC} \geq 0.5$.

Berdasarkan pernyataan tersebut maka nilai PIC gen TLR4|MscI pada ayam Tolaki dan ayam petelur termasuk kategori sedang. Adapun nilai PIC pada ayam broiler kategori rendah, hal ini disebabkan karena ayam broiler merupakan syntheticbreed of chicken yang keseragamannya sangat tinggi.

\section{SIMPULAN DAN SARAN}

Gen TLR4 bersifat polimorfik pada ayam Tolaki, petelur komersial dan broiler, dengan ditemukan dua alel yaitu A dan G. Frekuensi alel G (pembawa sifat resisten) pada ayam Tolaki dan broiler sangat tinggi (0.82 dan 0.87). Genotipe gen TLR4|MscI ayam Tolaki berada dalam keseimbangan Hardy-Wienberg, dengan nilai informasi genetik sedang. Berdasarkan hasil penelitian ini gen TLR4|MscI pada ayam Tolaki dapat digunakan sebagai penciri genetik.

Untuk memenuhi permintaan daging ayam Tolaki yang rasanya terkenal lezat, dapat dicoba dengan mengembangkan final stock dari persilangan ayam Tolaki dan broiler yang keduanya memiliki alel G sebagai pembawa sifat tahan terhadap Salmonella $s p$ dengan frekuensi tinggi. Dengan demikian penurunan populasi ayam Tolaki bisa ditekan. Tidak dianjurkan melakukan persilangan antara ayam Tolaki dengan ayam petelur karena ayam petelur didominasi genotipe gen TLR4 pembawa sifat peka (AA) terhadap infeksi bakteri tersebut. 


\section{UCAPAN TERIMA KASIH}

Penulis mengucapkan terimakasih kepada Ditjen Dikti yang telah membantu mendanai penelitian ini melalui Penelitian Unggulan Strategis Nasional Nomor : 63/IT3.41.2/SPK/2013. Kepada Eryk Andreas SPt, MSi. diucapkan terima kasih atas pendampingannya selama pelaksanaan penelitian di laboratorium molekuler.

\section{DAFTAR PUSTAKA}

Abasht, B., M.G. Kaiser, J. van der Poel, S.J. Lamont. (2009). Genetic lines differ in Toll-like receptor gene expression in spleens of chicks inoculated with Salmonellaenterica serovar enteritidis. Poult Sci 88: 744749.

Akashi, S.Y., H. Nagai, M. Ogata, K. Oikawa, S. Fukase, K. Kusumoto, M. Kawasaki, S. Nishijima, M. Hayashi, Kimoto, K. Miyake. 2001. Human MD-2 confers on mouse Toll-like receptor-4 species-specific lipopolysaccharide recognition. Int. Immunol. 13:1595-1599.

Akira, S., K. Takeda. 2004. TLR signaling pathways. Nature Reviews Immunology 4: 499-511.

Allendorf, F.W., G. Luikart. 2007. Conservation and The Genetic of Population. Blackwell Publishing.

Animura, N.S., F. Saitoh, S. Matsumoto, T. Akashi, and K. Miyake. 2008. Roles for LPS-dependent interaction and relocation of TLR4 and TRAM in TRIF-signaling. Biochem. Biophys. Res. Commun. 368: 94-99.

Beaumont, C., J. Protais, F. Pitel, G. Leveque, D. Malo, F. Lantier, F. Plisson-Petit, P. Colin, M. Protais, P.L. Roy, J.M. Elsen, D. Milan, I. Lantier, A. Neau, G. Salvat, A. Vignal. 2003. Effect of two candidate genes on Salmonella carier state in fowl. Poul. Sci. 82: 721-726.

Botstein, D., R.L. White, M. Skolnick, R.W. Davis. 1980. Construction of genetic linkage map in human using restriction fragmen length polymorphisms. Amer J Hum Genet. 32 :314-331.

Calenge, F., P. Kaiser, A. Vignal, C. Beaumont. 2010. Genetic control of resistance to salmonellosis and to Salmonella carrier-state in fowl : a review. Genetics Selection Evolution 42:1-11.

Emertcan, A., F. Ozturk, K. Gunduz. 2011. Toll-like receptors and skin. Journal of the European Academy of Dermatology and Venereology 11:1-7.

Hartl, D.L., dan A.G. Clark. 1997. Principle of Population Genetic. Sunderland Sinauer Associates, M.A.

Kabelitz, D. (2007). Expression and function of Toll-like receptors in $\mathrm{T}$ lymphocytes. Curr Opin Immunol 19: 39-45.

Kramer, J., M. Malek, S. Lamont. 2003. Association of twelve candidate gene polymorphisms and response to challenge with Salmonella enteritidis in poultry. Anim Genet 2003. 34:339348.

Lamont, S.J., M.G. Kaiser, W. Liu. 2002. Candidate genes for resistance to Salmonella enteritidis colonization in chickens as detected in a novel genetic cross. Veterinary Immunology and Immunopathology 87, 423-428.

Li, H.F., Y. Hu, H. Hu, C. Song, J.T. Shu, C.H. Zhu, S.J. Zhang, H. Fan, W.W. Chen. 2013. Genetic differ in TLR4 gene polymorphisms and expression involved in Salmonella natural and artificial infection respectively in Chinese native chicken breeds. Mol. Biol. Rep. DOI: 10.1007/s11033-0132601-2608.

Liu, Y., G.B. Chang, W.B. Bao, K.H. Wang, 
X.Y. Zhang, G.H. Chen. 2011. Polymorphism of Exon 2 of TLR4 Gene and Its Correlation with Some Commercial Traits in Anka Chicken.African Journal of Biotechnology 10(42):8260-8266.

Lorenz, E., J.P. Mira, K.L. Frees, D.A. Schwartz. 2002. Relevance of mutations in the TLR4 receptor in patients with gram-negative septic shock. Arch Intern Med. 162: 10281032.

Malek, M., J.R. Hasenstein, S.J. Lamont. 2004. Analysis of chicken TLR4, CD28, MIF, MD2 and LITAF genes in a Salmonella enteritidis Resource Population. Poultry Sci. 83:544-549.

Nataamijaya, A.G. 2010. Pengembangan potensi ayam lokal untuk menunjang peningkatan kesejahteraan petani. $J$ Litbang Pertanian 29: 131-138.

Nei, M., and S. Kumar. 2000. Molecular Evolutionary Genetics. New York, Columbia University Press.

Nei, M. 1987. Molecular Evolutionary Geneticcs. New York, Columbia University Press.

Ochiai, R.L., C.J. Acosta, M.C. DanovaroHolliday. 2008. A Study of Typhoid Fever in Five Asian Countries: Disease Burden and Implications for Controls. Bulletin of the World Health Organization 86:260-268.

Pagala, M.A. 2014. Identifikasi Sifat Ketahanan Penyakit Viral Menggunakan Gen Mx sebagai Marka Genetik Pada Ayam Tolaki. Disertasi. Sekolah Pascasarjana, IPB. Bogor.

Palsson-McDermott, E.M., and L.A. O’Neill. 2004. Signal transduction by the lipopolysaccharide receptor Tolllike receptor-4. Immunology 113: 153162.
Ruan, W.K., J.H. Wu, J. An, S.J. Zheng. 2012. Polymorphisms of chicken TLR4, 5, 21 in different breeds. Poultry Sci. 91 : 2512-2516.

Sambrook, J., E.F. Fritsch, T. Maniatis. 1989. Molecular Cloning : a Laboratory Manual. United State of America, CSH Lab Pr.

Sulandari, S., M.S.A. Zein, S. Paryanti, T. Sartika, M. Astuti, T. Widjastuti, E. Sujana, S. Darana, I. Setiawan, D. Garnida. 2007. Sumberdaya genetik ayam lokal Indonesia. Keanekaragaman Sumber Daya Hayati Ayam Lokal Indonesia. Manfaat dan Potensi. Pusat Penelitian Biologi, Lembaga Ilmu Pengetahuan Indonesia, Bogor. pp: 45-104.

Ulupi, N., Muladno, C. Sumantri, I.W.T. Wibawan. 2013. Association of TLR4 Gene Genotype and Resistance Against Salmonella enteritidis Natural Infection in Kampung Chicken. Journal of Poul. Sci. 12(8):445-450.

Ulupi, N. 2014. Kajian Ketahanan Ayam Kampung terhadap Salmonella enteritidis menggunakan Gen TLR4 sebagai Penciri Genetik. Disertasi. Sekolah Pascasarjana, IPB.

Vasconcellos, L.P.M.K., D.T. Talhari, A.P. Pereira, L.L. Coutinho, L.C.A. Regitano. 2003. Genetic characterization of aberden angus cattle using moleculer markers. Genet Mol Biol. 26:133-137.

Velge, P., A. Cloeckaert, P. Barrow. 2005. Emergence of Salmonella epidemics : the problems related to Salmonellaentericaserotype enteritidis and multiple antibiotic resistance in other major serotypes. Vet. Res. 36: 267-288. 